\title{
Behavioral Economics and Government Purchases - Some Insights into the Fiscal Psychology of Public Expenditure
}

Thomas Döring ${ }^{1}$

Ruven D. Oehmke

REVIEW

ARTICLE

\section{ARTICLE INFO}

Submitted : 03.04.2020

Revised : 02.07.2020

Accepted : 07.07.2020

Available : 24.07.2020

iThenticate similarity

score: $4 \%$

JEL classification:

$\mathrm{H} 30, \mathrm{H} 50$

Keywords:

Behavioral Economics,

Public Expenditure,

Fiscal Psychology,

Fiscal Illusion

\begin{abstract}
A B S T R A C T
Behavioral economics have increased acceptance in public finance, thus challenging the neoclassical approach to human decision-making. However, so far, behavioral economics' fundamental results on cognitive heuristics, illusions, and biases with respect to human information processes, judgments, and choices were primarily applied to the analysis of taxation and public debt. In contrast, up to now equivalent examinations of public expenditure are not very common. The paper offers a review of the existing behavioral economic research on public spending and government expenditure policy to address this shortcoming.
\end{abstract}

Cite this article as: Döring, T. \& Oehmke, R. D. (2020). "Behavioral Economics and Government Purchases - Some Insights into the Fiscal Psychology of Public Expenditure", International Journal of Public Finance, 5(1), 56-80.

\section{Introduction}

Behavioral economic research becomes more and more prevalent as an alternative concept to the widely accepted neoclassical approach and its exaggerated assumptions regarding strict utility maximization, perfect information as well as

\footnotetext{
1 Prof. Dr., Darmstadt University of Applied Sciences, Germany, ORCID: 0000-0002-8327-4167, thomas.doering@h-da.de

2 Consultant, Darmstadt University of Applied Sciences, Germany, ORCID: 0000-0003-1786-5652, ruven.d.oehmke@outlook.de
} 
completely rational behavior only restricted by external factors (like income or prices) and guided by time-consistent preferences (Smith, 2005; Della Vigna, 2009). The criticism of the neoclassical model to human decision-making also reaches the domain of public finance. Behavioral economic analyses point out the need for an improvement of the current state of knowledge. Building on the early considerations of Schmölders (1960) regarding the psychology of taxation, matters like tax salience or tax evasion and compliance are examined in detail in order to embed the previous insights of public finance in a framework that matches better with human realities. Nevertheless, we can already perceive hints regarding psychological influences aside from purely economic factors in existing research on the increase of government expenditures over time.

A well-known example is a study on the impact of habitual effects by Peacock \& Wiseman (1961). Moreover, phenomena like a systematic underestimation of government expenditure costs ("fiscal illusion") or insufficient perception of intergovernmental grants resulting in a misjudgment by citizens regarding spending benefits and tax burden ("flypaper effect") have been discussed in public finance literature for quite some time (Buchanan \& Wagner, 1977; Oates, 1988; Wildasin, 1990; Wyckoff, 1991). Occasionally, you can also find younger publications concerning the application of behavioral economics and fiscal psychology in public finance (Bernheim \& Rangel, 2007; Congdon et al., 2011; Mullainathan et al., 2012; Kilavuz \& Yüksel, 2019).

Against this background, the paper on hand provides an overview of important behavioral economic research concerning the perception, mechanisms, and policymaking processes regarding public expenditure. For this purpose, chapter 2 sets out a summary of fundamental behavioral economic effects relevant for an analysis of public spending policy. Building on this, it will be explained in section 3 how perceived benefits, judgments about urgency, and considerations of fairness influence public expenditure perception by the beneficiaries of public services (chapter 3.1). Subsequently, it will be pointed out that the common impact analysis of government spending regarding distribution and economic stability is insufficient without taking behavioral economics insights into account (chapter 3.2). The latter also applies to the subjective perception of public expenditure that is quite frequently disturbed by cognitive biases like the already mentioned "fiscal illusion" or the "flypaper-effect" (chapter 3.3). Complementarily, political decision-making processes about public spending will be examined. As a result, it will be shown that existing politico-economic approaches fail to provide an appropriate explanation of these decision-making processes regarding public expenditure policies (chapter 4). Finally, some further inferences regarding public expenditure policies will be drawn (chapter 5). 


\section{Fundamental Insights from Behavioral Economics}

The government makes public expenditures while meeting the common needs and gets public revenues in order to realize these expenditures. Through these revenues, the goods and services necessary for the provision of public services are purchased and expenses are converted to public services. Therefore, we can express the public budget, which is the total of the expenditures made to meet the common needs of the society and of the revenues obtained to finance these expenditures, as a common wallet used for the common needs of the society. At this point, an important aspect is that this wallet is financed by the citizen and spent back on the provision of services to the citizen. This situation points to one of the important points where the personal wallet (budget) of the microeconomic actors (individuals and firms) and the common wallet (public budget) differentiate. In our study, based on these differences we preferred to express the public budget as a "common wallet" as a means of metaphor. At this point, we can define the concept of common wallet as follows: "It is a public resource that demonstrates the common income and common expenses of the citizen as a whole in a detailed way and provides the executive body with the authority to collect revenues and realize the expenses by using public authority and resources in line with the common interests of the society."

On the other hand, it is very important to evaluate all aspects of the concept of the common wallet, which develops and changes in a tightly coupled way with social dynamics. At this point, citizens' perception of the common wallet is an element that needs to be emphasized.

Although the concept of "common wallet" that we use through the metaphor exists in practice, it cannot be clearly understood due to some problems. The primary problem is that the citizens, who are the real owners of the resources that make up this wallet, are not aware that they are the owners, or that their awareness is weak. At that point, the weakness or weakening of perception will bring along some problems such as not using the resources correctly, loss of social sensitivity and awareness, and disruption of the audit process. An important factor in this undeveloped perception is that citizens do not show as much interest and responsibility towards the public budget, which is their common wallet, as they show towards their personal wallets. Therefore, it is not possible under these conditions to reflect social demands in public decision making.

Given the fact that the budget has political, economic, fiscal and legal consequences, it is clear how important it is to use it correctly and effectively. In this context, it is necessary to answer the question of "why citizens do not show the same sensitivity as they show towards their personal wallets when the public resources are not used correctly and efficiently", which is the starting point of our study. At this point, there are many factors that weaken the perception of common wallet. These elements can be listed as insecurity of law, corruption, media-trade-government relationship, the effect of liberal thought, the structure of civil society organizations, 
lack of publicity awareness, weakness of the awareness of citizenship, the role of education, psychological and sociological elements. However, in this study, we evaluated psychological and sociological factors.

From a behavioral economic viewpoint, the explanatory power of the standard model of individual decision-making behavior in economics can be increased by inserting insights from cognitive psychology (Camerer \& Loewenstein, 2004; Rabin, 1998; Conslik, 1996). In principle, the assumption of individual utility maximization with stable preferences is questioned because most human decisions occur intuitively and automatically, based on unconscious and learned behavioral patterns. These intuitive and automatic decisions are prone to systematic behavioral anomalies due to cognitive biases and the use of heuristics. Consequently, the use of the latter tends to reduce the rationality of individual choices (Kahneman, 2003; Thaler \& Sunstein, 2009; Kahneman, 2011). Additionally, deviations from entirely rational and utility-maximizing behavior can be the result of contextual influences on individual decision-making behavior, but also of social norms regarding fairness and reciprocity in a social setting (Fehr \& Schmidt, 1999; Güth et al., 1982) as well as psychological reactance. Concerning the analysis of public expenditure, the following determinants of individual decision-making processes are particularly relevant:

- Cognitive Biases - Due to cognitive biases, actors often fail to capture all relevant aspects of a decision-making scenario accurately. For instance, actors are prone to excessive optimism in complex social situations, i.e., they systematically underestimate the likelihood of being the victim of negative events while overestimating the likelihood of being the beneficiary of positive events (optimism bias). They also tend to be overly confident regarding their own knowledge and ability (overconfidence bias). Furthermore, actors are inclined to process new information only in accordance with their own interests (self-serving bias) and stick to their current option even though the change to an alternative option would be objectively viewed more lucrative (Kahneman \& Tversky, 1984). This phenomenon can be ascribed to the tendency to prefer the current situation and stick to it (status quo bias) as well as the fact that humans overestimate the value of objects they already own (endowment effect). Moreover, actors think that what they are currently considering is of high importance. This can lead them to concentrate narrowly on a few aspects while ignoring other relevant information (focus illusion). Finally, actors behave excessively risk-averse in situations of uncertainty, i.e., losses are weighted significantly higher than equivalent gains, and this leads to a so-called "loss aversion" (Kahneman et al., 1991; Kahneman \& Tversky, 1992).

- Application of heuristics - An example of heuristics' application is the use of mental anchors that prevent unbiased choices between options, i.e., actors rather tend to make decisions based on given benchmarks instead of evaluating the situation objectively without preconceptions (anchoring heuristic). Another significant effect is that actors do not mainly base their decisions on the relevant information given, but are rather influenced by information's ease of retrieval 
(availability heuristic). Finally, humans are inclined to ascribe a certain learned behavioral pattern to what they observe and think in stereotypes (representativeness heuristic). From a behavioral economic point of view, the application of heuristics, generally speaking, leads to negative consequences regarding the quality of decisions in new, complex, and poorly structured decision scenarios (Camerer \& Loewenstein, 2004; Elster, 1998).

- Context-dependent behavior - Individual decision-making is determined not only by given restrictions like product prices and available income. Decision-making behavior is also influenced by the way the decision-making scenario is presented (framing effect). The description and presentation of the different options in a scenario are significantly relevant for the actual decision (Thaler, 1985; Kahneman \& Tversky, 1984). Therefore, different decompositions of an option can lead to other preferences regarding the various wordings of the same option, although they are factually identical (isolation effect). Furthermore, actors often form their specific preferences during the decision-making process.

- For this reason, preferences are not stable and time-consistent but dependent on the context of the situation (Bettman et al., 1998; Payne et al., 1992). After all, actors are easily influenced by the communication and decisions of others (herding effect). This is even more enhanced by the spotlight that describes individuals' tendency to think that others pay a lot more attention to their behavior than they actually do, thus increasing the perceived pressure on the individual to adapt.

- Social norms of fairness - Behavioral experiments revealed that social norms of fairness and reciprocity characterize the decision-making behavior of most participants. However, it is debated if the shown behavior is the consequence of aversion against inequality (Thaler 1988; Henrich et al. 2004), a general preference for average values (Bolton \& Ockenfels 2000), or merely strategic contemplation motivated by self-interest (Smith 2008). In this context, equity theory postulates that actors focus on a balanced input-output ratio when they evaluate exchange relationships. This supports the thesis that social norms of fairness and reciprocity are relevant determinants of behavior. Trust and trustworthiness are also concerned, whereby the latter can cause actors to accept disadvantages in order to protect existing fairness norms (Rabin, 1993; Jolls et al., 1998).

- Reactant behavior - In its original form, the theory of psychological reactance tried to explain how people respond to a subjectively experienced loss of their freedom. The latter can be understood as a state in which previously available options become (unexpectedly) unavailable. Psychological reactance is the response to such a loss, which can be interpreted as the attempt to regain the lost freedom of choice (Wortmann \& Brehm 1975). Although psychological reactance traditionally means the response to losses of options or control over options, it can also be interpreted as the attempt to reestablish violated social norms as a response to the behavior of others experienced as unfair and unjust. 
Döring, T. \& Oehmke, R. D. (2020). "Behavioral Economics and Government Purchases - Some Insights into the Fiscal Psychology of Public Expenditure", International Journal of Public Finance, 5(1), 56-80.

Table 1 contains a summing of the various psychological determinants, all of which are relevant for a proper understanding of individual decision-making. The subsequent considerations will draw different cause-effect hypotheses and recommendations concerning public expenditure policy from these general insights of behavioral economics.

Table 1. Important Psychological Determinants of Individual Decision-Making

\begin{tabular}{|c|c|}
\hline \multicolumn{2}{|l|}{$\underline{\text { Cognitive biases }}$} \\
\hline Optimism bias & $\begin{array}{l}\text { Underestimating the likelihood of being the victim of negative events } \\
\text { systematically }\end{array}$ \\
\hline Overconfidence bias & $\begin{array}{l}\text { The tendency to be overly confident regarding their own knowledge and } \\
\text { behavioral abilities }\end{array}$ \\
\hline Self-serving bias & Processing new information only in accordance with their own interests \\
\hline Status quo bias & Resistant to change due to preferring the current situation \\
\hline Endowment effect & Overestimating the value of objects already owned \\
\hline Focus illusion & $\begin{array}{l}\text { Concentrating narrowly on a few aspects while ignoring otherrelevant } \\
\text { information }\end{array}$ \\
\hline Loss aversion & Behaving excessively risk-averse in situations of uncertainty \\
\hline \multicolumn{2}{|l|}{ Decision heuristics } \\
\hline Anchoring heuristic & $\begin{array}{l}\text { Making decisions based on given benchmarks instead of evaluating a } \\
\text { situation objectively }\end{array}$ \\
\hline Availability heuristic & Making decisions being influenced by information's ease of retrieval \\
\hline $\begin{array}{l}\text { Representativeness } \\
\text { heuristic }\end{array}$ & The inclination to think in stereotypes by ascribing the behavior of others \\
\hline \multicolumn{2}{|l|}{$\underline{\text { Context effects }}$} \\
\hline Framing effect & Being influenced by the way a decision-making scenario is presented \\
\hline Isolation effect & $\begin{array}{l}\text { Influence of the different decompositions of an option on the emergence } \\
\text { of individual preferences }\end{array}$ \\
\hline Herding effect & Being influenced by the communication and decisions of others \\
\hline \multicolumn{2}{|l|}{ Normative judgments } \\
\hline Fairness and reciprocity & $\begin{array}{l}\text { (1) The aversion against inequality; (2) Being focused on a balanced } \\
\text { input-output ratio when evaluating exchange relationships }\end{array}$ \\
\hline Reactance & $\begin{array}{l}\text { (1) Response to a loss of options or control over options;(2) Response to } \\
\text { the behavior of others experienced as unfair or unjust }\end{array}$ \\
\hline
\end{tabular}

Source: Own Compilation. 


\section{Government Expenditure form a Behavioral Economic Perspective}

In those areas where behavioral economic analyses reach beyond the traditional conclusions of public finance, they can enrich the theoretically and empirically derived assessment of government spending. Even in those areas where the behavioral economic perspective does not bring new fundamental insights, it can help to provide additional proof for already existing recommendations. Since the behavioral economic analysis of public expenditure focuses on (1) the subjective perception of public spending, (2) the efficacy of public spending impulses, (3) the inefficiency of intergovernmental fiscal relations due to psychological effects as well as (4) the political process of government's public spending decisions, the following explanations will respectively concentrate on these four topics.

\subsection{Subjective Acceptance, Individually Estimated Urgency and Perceived Fairness}

Concerning citizens' subjective acceptance of specific public spending decisions as well as the government's public expenditure policy in general, Kirchler (2007) describes the fact that subjective acceptance of public expenditure is not independent of the individually experienced tax load as one of the central findings of behavioral economics. Early studies by Spicer \& Lundstedt (1975) about the psychology of taxation already revealed that public revenues and public expenditure are subject to a cost-benefit analysis by citizens. Thus, citizens try to determine in accordance with psychological equity theory, if the ratio of their individual tax load and the received benefits from public expenditure is fair or unfair. For this comparison, it is also relevant if it comes with a feeling of fairness regarding government spending. Accordingly, it should be expected that public spending is perceived as unjust and charged taxes are seen as unfair, if someone has the impression to benefit significantly less from public spending than the majority of citizens. In this case, it is completely irrelevant if this assessment lines up with the objective figures since it is solely the subjectively perceived relationship between public spending and charged taxes that matters. The subjective impression of citizens that the state withholds from them benefits of public spending that they believe they are entitled to (self-serving bias) can erode trust in the state and even to a profound crisis regarding the state's legitimacy.

Nevertheless, citizens also tend to perceive long-existing practices of government spending just as if their existence is totally arbitrary and random. From a behavioral economic perspective, this is an expression of status quo bias or, in accordance with Wood \& Neal (2007), a habitual behavior. Such protection of vested rights and habitual effects consequently leads to path dependencies and obstacles to a development resulting in less flexibility for public finance policies. It is important to mention that for the subjective assessment of tax load related to public spending benefits, both are usually not equally weighted. Kahneman \& Tversky (1979) have already pointed out this asymmetric perception of benefits (gains) and costs (losses) in 
principle. Transferred to public expenditure, benefits from government spending produce a subjective feeling of increase.

In contrast, public financing through taxation produces an individual feeling of loss, which triggers the earlier mentioned loss aversion. Schmölders (1970) also demonstrates that although expense cuts and tax increases are functionally equivalent means for budgetary consolidation, they differ significantly concerning the level of loss aversion. Consistent with prospect theory, affected citizens experience the forgoing of a gain (expense cutting) less "painful" than the loss of their own assets (tax increase).

Another important point is the usual absence of psychological reactance to public spending - comparable to public debt (Döring \& Oehmke, 2019) - in contrast to taxation since funded public services enlarge the economic scope of freedom. Nevertheless, citizens' reactance can occur when the government reduces public expenditure instead of increasing it to consolidate the budget. This can even lead to a kind of resistance associated with a compulsive character, whereas psychological reactance can even be enhanced by the status quo bias or the endowment effect. Accordingly, beneficiaries perceive long-existing public expenses as part of their own income or assets (Kirchler, 1999). The reactant behavior towards public expenditure cuts is also more intense if the affected expenses are especially salient or positively associated.

Moreover, it is important to mention that those public expenses that are more collective in their nature (e.g., defense expenses) are less noticeable compared to those that are more individual (e.g., education expenses). The degree of noticeability of public expenditure is also influenced by the frequency of use for public service. Furthermore, it depends on whether the service has an immediate benefit (e.g., social spending) or a merely optional benefit (e.g., national defense). This results in stereotypical judgments about the urgency of public expenses in different public sectors (Kirchler, 1997). Accordingly, additional public expenditures for national defense or foreign politics are often considered dispensable. In contrast, other public expenses for education or social services are viewed as desirable for the most part.

Judgments about the urgency of public expenses are not only influenced by noticeability or individual involvement but also by citizens' risk behavior. According to expected-utility theory, rational actors are able to attribute the right probability values to chance events consistently. However, with reference to Kahneman \& Tversky (1979), reality shows that subjectively experienced probabilities of risks differ significantly from objective probability values. This phenomenon helps explain citizens' panic even in light of small risks for catastrophic events that lead to inappropriately high public expenses for preventive measures, although they cannot be rationally justified based on the minimal risk. Regarding the irrational handling of risks, it should be noted that humans tend to react overly intensive to threats that they have experienced or that occurred among their peers, as well as threats connected to dramatic images or frequently mentioned in the public discussion. This is due to the 
availability heuristic and can lead to irrational "availability cascades" in the evaluation process of risks (Kuran \& Sunstein, 1999). If politicians simply adapt to citizens' irrational behavioral patterns, the allocation of public expenditure will be suboptimal compared to an allocation based only on the objective extent of threats.

Several inferences can be drawn from these research results of Behavioral Economics. First, the observed stereotypical way of making judgments about public expenses leads to the conclusion that widespread public acceptance of government's expenditure can only be achieved if the (economic) reasons for certain decisions concerning public expenses are not only communicated to citizens in a simple, clear and comprehensible manner but also repeatedly. Furthermore, citizens' stereotypical judgment behavior makes it extremely difficult, except in times of severe economic and societal crises, to implement deep structural reforms in those political areas that are actually very cost-intensive (social services and personnel expenses). After all, the referenced studies reveal a clear tendency that the state is always confronted with additional demands of substantial volumes. With respect to this, Schmölders (1970: 32) already noted: "There is no doubt that the list could be extended infinitely; the entitlement to services that are expected to be offered by the state is the central element of the development to a welfare state which is also labeled a little bit maliciously as 'democracy of favors' nowadays." The state could respond to the resulting fiscal overload due to citizens' demand labeled directly contrasting the expected benefits from public expenses with the considerable monetary burden of these expenses.

\subsection{Effects on Aggregate Demand, Income Redistribution, and Motivation}

Concerning the effects of public expenditure on aggregated income and demand, it is assumed in traditional public finance that a change in government spending leads to multiplying processes within the economic cycle. As is known, the multiplier effect refers to the idea that an initial public spending rise can lead to an even greater increase in national income. In other words, an initial change in aggregate demand can cause a further change in total output for the economy. In this process, the extent of the income effect is defined by the extent of the so-called primary effect and the extent of the multiplying process's influence. In turn, the initial impact is presumed to be determined by the state's choices regarding public spending (e.g., increased spending for infrastructure vs. higher public staff expenditure).

In contrast, the secondary effect is a result of private actors' spending behavior (i.e. businesses and private households). Furthermore, it is supposed that the marginal propensity to consume or respectively, the savings ratio of private households and the induced investments of companies are the primary determinants of private demand (see paradigmatic Mankiw, 2018). In essence, traditional multiplier analysis is shaped by a "mechanical" understanding of short-term effects on income and demand. Research in 
behavioral economics can help to draw a more differentiated picture of private actors' behavioral reactions in the context of stability-oriented public spending politics.

Accordingly, considerable income and demand effects, in addition to the primary impact of further public spending, are not dependent on individual expectations only that are already considered in the traditional approaches. At this point, a few factors that are usually not a considerable part of the discussion in public finance have to be mentioned: First, the sufficient subjective noticeability of changes in income induced by public expenditure policies is a condition for additional private demand. In contrast to the standard multiplier analysis, this condition cannot be assumed as given. Furthermore, increases in public expenditure only result in a multiplication of overall economic demand if private economic entities interpret the accompanying changes in income as a sustained expansion of their possibilities for consumption or capital investment activities. According to Kahneman \& Tversky (1984), this psychological effect is enhanced even further by humans' tendency to maintain their already-made decisions (status quo bias) that come with subjective resistances against alternative options. Applying the general contemplations of Thaler \& Sunstein (2009) to public expenditure policy, a sufficient "stimulus-response compatibility" is mandatory for the multiplier effect. Otherwise, private spending behavior remains unaffected despite public expenditure stimuli. The latter is especially the case if such an expenditure stimulus takes place during a time of severe (collective) pessimism concerning future economic development (framing effect). During such times, actors usually do not consider increasing their consumption as a critical possibility of action.

The herding effect can enhance a lack of stimulus-response compatibility that Keynes pointed out (1936). He considers the situational judgments of market participants as primary relevant, which are - in his view - "the outcome of the mass psychology of a large number of ignorant individuals" (ibidem: 154). Consequently, the market will be subject to waves of optimistic and pessimistic sentiment, which are unreasonable and yet, in a sense, legitimate, where no solid basis for a rational calculation exists. According to Akerlof \& Schiller (2009), it is especially the importance of "animal spirits" that is emphasized by Keynes (1936), which points out the necessity for behavioral economic analysis. Thus, herding behavior can be driven by rational as well as irrational motivations. In behavioral economics, the primary focus lies in searching for arguments for the irrational type of herding behavior. Two factors of human behavior play a significant role concerning herding behavior: First, there is the desire of humans not to be the only one within a group that holds certain opinions or commits specific actions. Furthermore, actors tend to imitate other actors' behavior, especially in very anonymous situations like a market context. Overall, the referenced psychological effects suggest that the effectiveness of public spending policy with the aim to stabilize economic development is considerably limited. 
A state's public expenditure policy does not only bring forth aggregate income and demand effects. Usually, public spending comes also with effects on the (re)distribution of wealth among private households. One of the central insights from behavioral economics is that there must be a distinction between the objectively identified effects of public spending on wealth distribution, and the subjectively experienced distribution effects. Empirical research results reveal that individual judgments about satisfaction and justice of redistribution policy are not primarily based on changes in total income, but are dependent on existing relative income levels as a reference point (Ferrer-i-Carbonell, 2005; Grund \& Sliwika, 2007; Clark et al., 2009). Thus, (re)distribution effects of government spending only improve recipients' well-being and happiness if they increase their relative and not only their absolute income level. This is the case since subjective decisions usually refer to reference values, similar to the well-known anchor heuristic. In this context, the reference value could be represented by a person's previous own income (internal reference income) as well as the current income of some other person (external reference income). In connection with this matter, a particular problem comes up. Actually, empirical evidence reveals that such reference points are subject to dynamic changes due to habituation effects that quickly lead to an adjustment of the inner comparative yardstick. Applied to the internal reference income, this often means regarding wellbeing that increases in income due to government social transfers are only interpreted the short term as the result of the state's (re-)distribution policy (Brickman et al., 1978; Praag \& Frijters, 1999).

With respect to the government's redistribution policy, the so-called hamster wheel effect presents a significant challenge. It describes the human tendency to continually pursue constantly higher income levels, although it is not necessarily connected to higher levels of personal wellbeing. Analogous to the effects of (income) taxation demonstrated by Layard (2005), government transfers affect not only the decision-making behavior of immediate recipients but also the behavior of other people since it leads to a change in their relative income position. This causes undesired effects concerning economic efficiency. The hamster wheel effect prompts those who are not recipients of transfer payments to increase labor supply in the pursuit of higher incomes. The consequence is a (negative) externality in the form of an inefficient enlargement of the overall labor supply.

In light of potential inefficiencies caused by government social transfers, the motivational effects of such transfers also gain in importance. In this context, the behavioral economic perspective supports the commonly postulated rule that social benefits should be clearly below the average employee's wage. However, in contrast to the general view in public finance, behavioral economics argues for this rule with the anchor effect. It suggests that the amount of government transfers serves as a reference point that sustainably influences the perceived justice of realizable incomes on the labor market. This effect is described by Falk et al. (2006) in their analysis of the incentivizing impact of minimum wages, which can also be applied to public expenses 
for basic social security. Behavioral experiments have demonstrated that the introduction of a minimum wage comes with a shift of the subjective reference point that determines if a certain wage rate is considered fair in relation to the required workload. Following Bewley (2004), test persons assessed low wages as justified or even generous as long as there was no mandatory minimum wage level. However, the introduction of a minimum wage led to a rapid change in the participants' view. Suddenly, salaries offered by companies below the new minimum wage rate were judged as "exploitative" or "stingy". Likewise, granting social transfers can have a similar incentive effect. If the wage rate is not substantially higher than the allowed amount of social transfers, it is perceived unjust and does not motivate people to earn their own income instead of receiving social transfers. According to Caplan (2007), this effect is enhanced by the fact that the majority population has a limited understanding of market mechanisms insofar as generated income on the labor market and social transfers are treated as equivalent.

Concerning the incentive effect of social transfers, Beaulier \& Caplan (2007) also argue that these transfers encourage recipients to behave in a time-inconsistent manner. The positive short-term effects of social transfers cause people not to earn their own income. However, in the long run, such behavior results in severe disadvantages for the recipients. This is the case because, especially, low-income households tend to underestimate the negative long-term consequences of their dependency on social transfers, i.e., the degradation of their human and social capital resulting in lowered chances of re-entering the labor market. In contrast, time limits, clear rules of conduct, reductions as well as cancellations of social transfers can help to correct recipients' time-inconsistent behavior. In turn, Mullainathan \& Shafir (2013) critically noted that recipients usually ignore long-term time limits on social transfers for the majority of the duration period. Only when the deadline draws near, recipients become aware of the threat posed by the end of social transfer payments, and then, it is already too late. Therefore, incentives linked to social transfers can only facilitate behavioral change if they enter into the perceptual field of recipients. This is in accordance with results from behavioral experiments conducted by Ariely \& Wertenbroch (2002) and Kurtz (2008), showing that a sequence of immediate deadlines has a more substantial impact on behavior than only one long-term period. Moreover, the noticeability of time limits on social transfers can be increased by a stepwise reduction of transfer payments over a longer space of time.

Nevertheless, the positive impact of such a reduction of welfare rates on employment behavior is still controversially debated. This can be explained by the psychological phenomenon called learned helplessness. It occurs when poverty or unemployment is interpreted as a consequence of an uncontrollable situation and not as a condition caused by one's own behavior. Seligman (1975), as well as Abramson et al. (1978), have noted quite early that intense experience of truly uncontrollable situations can result in a subjective feeling of powerlessness, which is also falsely applied to actually controllable situations. Concerning the incentive effects of social 
transfers, this means that it is not the amount and form of transfer payments but the perceived cause-and-effect relationships of unemployment and poverty that determine primarily the individual's willingness to earn an income. Furthermore, the existence of learned helplessness suggests that the design of social transfers should be primarily focused on the distributional effects and only secondarily on the potential incentive effects since the latter is still ambiguous from a behavioral economic viewpoint.

\subsection{Fiscal Illusion, Flypaper Effect, and Unstable Preferences}

A first reference to the relevancy of subjectively biased perception of government spending can be found in Downs' (1960) economic theory of democracy. Following the implications of his theory, public budgets (and thereby public expenditure) can turn out relatively smaller than a budget defined as "optimal". A phenomenon called "fiscal illusion" was identified as the cause of the issue. The term "fiscal illusion" describes the systematic misjudgment of the governmental fiscal burden in relation to the utility created for citizens by public expenditure. According to Downs (1960), the public budget turns out too small if the benefit of public expenses is ascribed to a lower value compared to the utility losses associated with public revenue. This contrasts with the more common view on the fiscal illusion that supposes an exaggerated enlargement of the public budget. This is due to the high noticeability of public spending in combination with an underestimation of the fiscal burden associated with public spending (Buchanan, 1967; Buchanan \& Wagner, 1977; Oates, 1988). The reverse interpretation of fiscal illusion can be explained by the fact that tax payments are usually perceived much more clearly than the benefits from public goods, which can result in a lower level of public expenditure.

The asymmetric perception of public expenditure and the tax burden is supported by a study conducted by Kirchler (1997) that asked participants to estimate the tax burden and benefit of public expenditure. Most participants were inclined to underestimate the level of public expenditure and the associated benefits compared to the disadvantages of public spending. Similar evidence for such misjudgments provides a study by Lewis (1983) that asked test persons to state the perceived benefits of public expenditure as well as their preferences concerning public expenditure policy. The study shows that those who perceived a lower benefit from certain public expenses preferred to increase spending in this area, while those who perceived a higher benefit from them preferred to decrease spending in this area by saving tax money. Moreover, the findings of Tomkinson \& Bethwaite (1991) verify the supposed link between subjective judgments and individual preferences.

Additionally, they observed that participants' preferences regarding fiscal matters are not stable at all. At the beginning of the study, participants were asked about their preferences concerning the structure of the public budget. However, these preferences changed when participants were confronted with the actual overview of 
the state's expenditure and revenue. Subsequently, they adjusted their personal preferences concerning public spending and financing to the given circumstances. Cruces et al. (2011), as well as Coté et al. (2015), find similar empirical results with respect to the view of private households on the governmental redistribution policy. Following, in turn, the research results of Variyam \& Jordan (1991) concerning the subjective evaluation of agricultural subsidies by the state, the extent of citizens' asymmetric perception of public expenses (benefits or gains) and the associated tax burden for funding them (costs or losses) is also dependent on the political communication of such measures (framing effect). Thus, the test persons judged agricultural subsidies as less negative when it was communicated that they were supposed to support small businesses and family businesses instead of the agriculture industry.

From a behavioral economic point of view, there is another important version of the fiscal illusion called "flypaper effect" (Bailey \& Connolly 1989, Wildasin 1990, Wyckoff 1991; Roemer \& Silvestre 2005). This effect describes citizens' biased perception of transfer payments between the different levels of government in a scenario in which typically the lower level (regional government) receives tax-funded transfer payments from the upper level (federal or state government). As long as these transfer payments do not lead to a positive income effect on the lower level, such transfers should not influence rationally-behaved citizens' preferences. This is the case if citizens would contrast one-to-one their tax contribution to these intergovernmental transfers with the benefit they receive from those expenses. However, if you suppose an existing fiscal illusion like Courant et al. (1979) or Oates (1979), you will observe citizens' differing behavior as the result of their biased perception. The implications of this effect are well described by Oates (1988: 77): "What the electorate sees is a reduction in tax rates needed to finance local spending programs, and this reduction is erroneously viewed as a reduction at the margin in the 'tax price' of these programs. The budgetary process thus transforms what is, in this, a lump-sum interrnmental grant into what is perceived by individuals as a reduction in the tax-price of local public goods. The result is a willingness on the part of the local electorate to support higher levels of spending than if they correctly perceived the relevant fiscal parameters."

According to Hines \& Thaler (1995), this indicates that the origin of the inflow of funds to the public budget also influences the spending of these funds. Instead of using the intergovernmental transfers to lighten the citizens' tax burden, the funds stick with the public budget ("The money sticks where it hits.") and are used to increase public expenditure. Thus, the efficiency of the supply of public goods is lowered. Due to the flypaper effect, a higher volume of public goods is demanded and funded compared to the outcome of a rational evaluation of marginal utility and marginal costs. In other words, the fund's origin induces a framing effect that is largely responsible for the extent of public expenditure. Meta-studies concerning the empirical evidence for the flypaper effect by Oates (1988) as well as Dollery \& 
Worthington (1996) confirm the real existence of the impact. Admittedly, there is an important assumption concerning the occurrence of the flypaper effect. For in order to work, it requires the absence of learning processes regarding the intergovernmental allocation of fiscal resources and financing the additional expenses based on citizens' tax payments. However, if citizens are aware that intergovernmental transfers are ultimately only fundable by already existing tax revenues, this knowledge should cause a stricter control of public expenditure behavior. Table 2 sums up the main findings of behavioral economics regarding public expenditures discussed so far in chapter 3.

\section{Table 2. Main findings of behavioral economics regarding public expenditures}

\section{Acceptance estimated urgency and perceived fairness of public expenditures}

1. Citizens' acceptance of public expenditures depends mainly on (1) the individually experienced tax load and (2) the impression of how to benefit from public spending in relation to the majority of citizens.

2. A long-existing practice of government spending will often be perceived as just even if their existence is totally arbitrary and random.

3. The degree of noticeability of public expenditures depends on (1) the frequency of use for public service, (2) the type of benefit (immediate vs. merely optional), and (3) the nature of public service (more collective vs. more individual).

4. The matter of the fact that humans tend to react overly intensive to threats that they have experienced themselves or that occurred among their peers can lead to a misallocation of public expenditures compared to an optimal allocation that is based on the objective extend of threats only.

Effects on aggregated demand, income redistribution a motivation

1. Compared to traditional multiplier analysis, which is shaped by a "mechanical" understanding of effects on income and demand, the private spending behavior remains unaffected despite the public expenditure stimulus if there is not sufficient "stimulus-response compatibility".

2. Due to the herding effect, the effectiveness of public spending policy with the aim to stabilize economic development is considerably limited.

3. Redistribution effects of government spending only improve recipients' state of wellbeing and happiness if they increase their relative and not only their absolute income level.

4. Social transfers do affect not only the decision-making behavior of immediate recipients but also the behavior of others since it leads to a change in their relative income position producing the inefficient so-called Hamster wheel effect.

5. Low-income households tend to underestimate the negative long-term consequences of their dependency on social transfers, i.e., (1) the degradation of their human and social capital as well as (2) the psychological phenomenon of "learned helplessness".

Effects on the public budget and intergovernmental fiscal relations

1. Asymmetric perception of public expenditure and tax burden by citizens.

2. Public budget turns out to small if the benefit of public expenses is ascribed to a lower value than the utility losses associated with public revenue.

3. High noticeability of public spending, in combination with an underestimation of the tax burden, leads to an enlargement of public budget (fiscal illusion).

4. The inflow of funds to the public budget influences the spending of these funds, i.e., intergovernmental transfers in contrast to tax revenue lead to an extension of public expenditure (flypaper effect).

Source: Own Compilation. 


\section{Public Spending Policy and Behavioral Anomalies of Political Actors}

Apart from the fiscal illusion, there are further determinants for citizens' perspective on the government's expenditure policy. Relevant studies on this topic can be found in the new research field of "behavioral political economy". According to Schnellenbach \& Schubert (2015), this research field aims to analyze the behavior of different political actors by using behavioral economic insights. For instance, the concept of a significant benefit associated with voting, as highlighted by Hamlin \& Jennings (2011), is referenced in this context. This concept describes a supposedly positive effect of voting behavior that is independent of the actual election results. Empirical evidence for this effect is provided by studies from Jones \& Hudson (2000) as well as Tyran (2004). Accordingly, the voting process does not serve the pursuit of political matters or interests. Still, it is an instrument to confirm one's own identity, validate policies that are perceived as morally superior, or express gratitude towards a political candidate. If voting behavior is heavily influenced by the desire to realize an expressive benefit, public expenditure programs that only benefit a minority of the population can easily obtain a political majority. This is described by Hillman (2010) as "case of deceptive expressive behavior" that potentially leads to unintended social costs for the whole of society.

Moreover, behavioral economic experiments reveal that voters tend to overestimate their own competence (overconfidence bias) concerning the understanding of the interdependence of different political subject areas (foreign affairs, domestic policy, educational policy, welfare policy, etc.) on a regular basis. According to Frey \& Eichenberger (1991: 75), this includes the following observation: "If politics leads to unfavorable results, people wrongly believe that this was foreseeable. Therefore they blame government for having committed a grave mistake." Considering this belief in their supposed ability to sufficiently comprehend political interrelations, voters often voice extreme opinions regarding various policy fields. This could be expressed for instance, by simply claiming in an undifferentiated manner that too high benefits of the welfare system are the driving motive for immigration. Concerning this matter, empirical research conducted by Fernbach et al. (2013) shows that the voters' overconfidence cannot be treated by merely demanding a proper justification for their line of reasoning, since this only causes them to search actively as well as selectively for arguments supporting their view instead of performing a balanced investigation of the matter (self-serving bias).

In fact, this "illusion of comprehension" can most effectively be cured by asking voters to explain such a complex issue. This helps voters to become aware of their own limited knowledge and consequently moderates extreme opinions on the state's public expenditure decisions (Linville 1985). Furthermore, easy heuristics like the characteristics "trustworthiness" and "sympathy" are often used as a foundation for the assessment of eligible politicians and their public expenditure programs. Additionally, the characteristics attributed by the media to certain spending areas 
("important", "subordinate" etc.) or political candidates that stand up for specific spending areas ("likeable", "assertive" etc.) are relevant for the voters' perception of the various public expenditure areas. Therefore it can be concluded, that it is insufficient to merely present the (economic) usefulness of public spending programs in a persuading manner in order to get the citizens' approval for them. In fact, the government also needs enough political sympathy and trustworthiness among citizens as well as a positive presentation and assessment in the reporting media.

From a behavioral economic viewpoint, the insight that political attitude patterns are strongly dependent on framing effects, is closely related to this matter (Quattron \& Tversky 1988; Chong \& Druckman 2007). Accordingly, it significantly impacts voters' acceptance of one and the same public expenditure program if it is described, for example, as "against unemployment" or "for the creation of new jobs". These results demonstrate the situational formability of political preferences that has been investigated in various studies about the influence of individual perception biases on voters' behaviors (Kuran 1991; Kuran \& Sunstein 1999). In light of the above, it can actually be quite "rational" for politicians to realize inefficient but popular political measures despite their better knowledge. If voters' misperceptions lead to a systematic underestimation of the cost of public expenditure programs, the already mentioned fiscal illusion occurs.

According to behavioral political economy, "irrational" decisions do not only characterize voters' behavior but can also be a characteristic of politicians' and bureaucrats' behaviors. The latter two groups of political actors also tend to make biased political decisions and do not always choose the option with the highest expected utility. According to Milkman et al. (2012), this leads to the observation that it is much easier in the context of public finance decisions to achieve a political consensus for actions that bring citizens a monetary benefit like increasing welfare rates than for those that come with financial losses for citizens like the implementation of a car toll. However, in order to make sure that also unpopular plans concerning the public budget get a fair chance to succeed politically, gains should only be compared with gains and losses should only be compared with losses during the negotiation process over the budget. Applying this principle to our previous example, it would make perfect sense to debate the benefits and costs of a car toll for example together with the benefits and costs of increasing the car tax. Likewise, the benefits and costs of increasing welfare rates should be compared for instance with an increase of education expenses.

Furthermore, politicians are also guided by their subjective conceptions about the consequences that come with their political decisions. Additionally, politicians quite often adopt the political decision-making heuristics used by the voter groups that are relevant to them. An example for this form of adaptive behavior is the common idea among US politicians that tax cuts automatically lead to public expenditure cuts although tax cuts commonly result in an increase of public debt (Baron \& McCaffrey 
2008). Conversely, it cannot be ruled out that political decision-makers might simply exploit citizens' perceptual errors in order to promote their own agenda. Nevertheless, both challenge the traditional assumption in public finance research that fiscal and economic policy serve as a corrective measure for the voters' deficits in rationality. Moreover, this assessment is supported by Mullainathan \& Shafir (2013: 118) who point out the tendency of the incumbent government to set the "wrong" priorities: "A similar focus on the urgent at the expense of the important has long been observed in the workings of governments that, over decades of tight budgeting, have slashed spending on infrastructure. The upkeep of bridges, for example, is a critical investment. Yet it is one that is all too easy put off when budgets are tight and cuts are needed." Accordingly, this behavior has a far-reaching impact on the state's expenditure and budget policy because politicians "reach repeatedly for the most proximate solution to the most immediate problem, over time these short-term fixes create a complex web of commitments. The result is a messy patchwork of assets and obligations" (ibidem: 128).

Therefore, Cooper \& Kovacic (2012) suggest limiting the existing biases regarding the decision-making process in public expenditure politics by additionally providing information through the public administration. Thus, an independent thirdparty role is assigned to the state's bureaucracy. Apart from the fact that from a behavioral economic perspective more information does not inevitably lead to better (or more efficient) political decisions, the actors in public administration are also not free from irrationalities and inefficiencies concerning their decision-making behavior. One example for this is found in the research by Charness et al. (2013) who showed through their behavioral experiment that just the provision of information about performance differences inside the public administration increases sabotage of the performance of competitors within the organization. With regard to such observations, it is certainly questionable if additional information provided by the bureaucracy can help to detect and correct inefficiencies in the behavior of political decision-makers. This skepticism is supported by the fact that political actors are not exempt from perceptual biases and thus tend to make erroneous decisions like all other human beings (Glaeser 2003). Thus it appears that political actors and bureaucrats (just like voters) ascribe a high level of importance to those topics that are currently debated in society and politics. If this concentration on day-to-day political matters leads to a neglect of additional information that is relevant to public expenditure policy, wrong decisions concerning the public budget cannot be ruled out (focus illusion). Furthermore, behavioral economic insights suggest that members of the administration probably tend to use the composition of former budgets to plan the new budget due to learned routines (status quo bias). Therefore, changes in the government's expenditure policy are executed slowly and the public budget continues to be similar in extent and structure. This behavior is supported by the fact that available information is analyzed and interpreted in accordance with former public expenditure decisions (self-serving bias). In consequence, all these effects lead to the 
phenomenon described by Wildavsky (1964) already as "budgetary incrementalism" that predominantly characterizes the public administration's decision-making process concerning budgetary and expenditure policy.

\section{Some (Additional) Implications for Public Expenditure Policy}

The previous explanations have clearly demonstrated that it is worthwhile to analyze the issue of public expenditure from a behavioral economic point of view. Behavioral economic insights provide additional value by systematically enlarging the empirical foundation for the analysis of expenditure in the domain of public finance. The focus, however, is not the complete rejection of the traditional (neoclassical) behavioral model in public finance and its replacement through insights from cognitive and social psychology. In fact, the existing impact analyses in public finance are complemented, and (if necessary) corrected using realistic assumptions about individual decision-making behavior and human information processing. This broader perspective comes also with specific implications for public expenditure policy. In addition to the recommendations for expenditure policy design already given, some further conclusions are highlighted as follows:

- From a behavioral economic view, the inefficiencies pointed out in the decisionmaking process for public expenditure policy can most likely be achieved by a stronger involvement of citizens and thus, a decentralization of decisions concerning the public budget. It has already been demonstrated in research about tax psychology, that a decentralized structure of the state helps to strengthen citizens' perceived identification with public institutions because such a structure makes the connection between one's own tax payments and public services (expenses) much more transparent. This is in accordance with the familiar economic call for more subsidiarity and fiscal equivalence in the structure of states in order to ensure a better match between the beneficiaries and financiers of public services. Similarly, it can also be concluded regarding public expenditure policy, that a more decentralized fulfillment of governmental tasks helps to mitigate fiscal illusion and increase acceptance of the state's expenditure policy among citizens because it is accompanied by greater transparency concerning the use of tax funds. For this very reason, further possibilities for a stronger direct participation of citizens in the state's policy making process should be developed. Here again, the involvement of citizens in the political decision-making processes tends to mitigate fiscal illusion and increase the identification with the state's expenditure policy.

- Temporal limitation of public services' provision is another important regulative implication for the design of public expenditure policy that can be drawn from behavioral economic insights. By setting an expiry date for all laws concerning public services, all public services and their related public expenses must be debated time and time again which counteracts habitual behavior in the sense of the status quo bias and the accompanying endowment effect on the part of 
Döring, T. \& Oehmke, R. D. (2020). "Behavioral Economics and Government Purchases - Some Insights into the Fiscal Psychology of Public Expenditure", International Journal of Public Finance, 5(1), 56-80.

citizens when it comes to the composition of the public budget. The suggestion of temporal limits for public expenses is nothing new in public finance research. However, the proposed measure aims at a different target group in this context: Traditionally, the expiration of public expenditure programs is used by the public administration as a means of self-discipline so that new and old expenditure programs have to be critically examined before they are included in the public budget. In contrast, the behavioral economic approach focuses on the use of this measure to avoid (inefficient) habitual effects on the part of citizens.

- If public expenses are used with the intention of income levelling, it should be considered that this does not lead to an increase of the overall economic welfare from a behavioral economic point of view. After all, the happiness gained by the beneficiaries of (re-)distribution programs is usually contrasted by the happiness lost by those whose position of income or assets is impaired. Such changes in relative income could only be avoided by increasing the share of those benefiting from the state's expenditure policy. However, this would definitely overstress the fiscal capabilities of the state and contradict the aim of (re-)distribution. Against this background, it can be concluded that the state's (re-)distribution endeavors are of much less importance than commonly supposed.

- From a behavioral economic perspective, the directional impulse going out from the government's expenditure policy is quite limited since incentives, behavioral constraints etc. that are linked to public expenditure programs do not automatically lead to the desired behavioral changes among the target group. This can be observed, for instance, in the case of public expenses aimed at the stabilization of the economy that fail to deliver substantial results due to the herding effect as well as the spotlight effect. The perception and mental processing of monetary and other stimuli varies widely depending on the context. This is one of the ways, if not the central way, in which behavioral economics contributes to microeconomics. In order to ensure an impact in accordance with the intended political goals, government measures should be crafted in a way that informs citizens regularly in a format that is easily understandable about the incentives and behavioral constraints.

In connection with public expenditure and taxation policy, more intense studying of the effects of monetary stimuli in alternative contexts should be the primary focus of public finance research informed by behavioral economics. First studies concerning this matter indicate, that besides the choice of the respective financial instrument the communicative shaping of the interpretative framework is a key factor in order to achieve the desired (steering) effects. Another pressing issue in relation to the context dependency of individual behavior, concerns the potential consequences for the state's expenditure policy that are caused by the social codetermination of preferences. This ties in perfectly with considerations in the field of fiscal psychology that already noted the importance of societal influences on economic decision-making behavior. In this context, Schmölders (1970, p. 49) speaks up for a concept he called "social-economic behavioral science" as a necessary empirical extension of the mainstream approach in public finance. Furthermore, these insights 
suggest that a universal theory about the impact of public expenditure, aimed for in traditional public finance, is only helpful to a limited extent. From a behavioral economic perspective, this is the case because the preferences for public spending as well as the perception and processing of stimuli from public expenditure policy are heavily dependent on the particular circumstances of the decision-making situation. Another important question to definitely grapple with, concerns the consequences that come with (completely) discarding the classical hypothesis of utility maximization in the context of public finance analysis. This approach has not yet been practically applied in public finance in general and has also not been adapted to the more psychological oriented research in this field. Against this background, there is a huge potential for further research on this topic and the opportunity to break new ground in the domain of public finance.

\section{References}

Abramson, L.Y., Seligman, M.E. \& Teasdale, J.D. (1978). "Learned Helplessness in Humans Critique and Reformulation", Journal of Abnormal and Social Psychology, 87(1), 49-74.

Akerlof, G.A. \& Shiller, R.J. (2009). Animal Spirits - How Human Psychology Drives the Economy, and Why It Matters for Clobal Capitalism, Princeton.

Ariely, D. \& Wertenbroch, K. (2002). "Procrastination, Deadlines, and Performance - Self-Control by Precommitment", Psychological Science, 13(3), 219-224.

Bailey, S. \& Connolly, S. (1989). "The Flypaper Effect - Identifying Areas for further Research", Public Choice, 95(3/4), 335-361.

Baron, J. \& McCaffery, E.J. (2008). "Starving the Beast - The Political Psychology of Budget Deficits", Fiscal Challenges - An Interdisciplinary Approach to Budget Policy, (Ed.) Garrett, E., Graddy, E. \& H.E. Jackson, Cambridge, 221-241.

Beaulier, S. \& Caplan, B. (2007). "Behavioral Economics and Perverse Effects of the Welfare State", Kyklos, 60(4), 485-507.

Bernheim, B.D. \& Rangel, A. (2007). "Behavioral Public Economics: Welfare and Policy Analysis with Nonstandard Decision Makers", Behavioral Economics and its Applications, (Ed.) Diamond P. \& H. Vartiainen, Princeton, 7-77.

Bettman, J.R., Luce, M.F. \& Payne, J.W. (1998). "Constructive Consumer Choice Processes", Journal of Consumer Research, 25(3), 187-217.

Bewley, T.F. (2004). Fairness, Reciprocity and Wage Rigidity, IZA Discussion Paper 1137, Bonn.

Bolton, G.E. \& Ockenfels, A. (2000). "ERC - A Theory of Equity, Reciprocity, and Competition", American Economic Review, 90(1), 166-193.

Brickman, P., Coates, D. \& Janoff-Bulman, R. (1978). "Lottery Winners and Accident Victims - Is Happiness Relative?”, Journal of Personality and Social Psychology, 36(8), 917-927. 
Döring, T. \& Oehmke, R. D. (2020). "Behavioral Economics and Government Purchases - Some Insights into the Fiscal Psychology of Public Expenditure", International Journal of Public Finance, 5(1), 56-80.

Buchanan, J.M. \& Wagner, R.E. (1977). Democracies in Deficit, New York.

Buchanan, J.M. (1967). Public Finance in Democratic Process, Chapel Hill.

Camerer, C.F. \& Loewenstein, G.F. (2004). "Behavioral Economics: Past, Present, Future", Advances in Behavioral Economics, (Ed.) Camerer, C.F., Loewenstein, G.F. \& M. Rabin, New York, 3-51.

Caplan, B. (2007). The Myth of the Rational Voter - Why Democracies Choose Bad Policies, Cato Institute Policy Analysis Series, No. 594 (May 29, 2007).

Charness, G., Masclet, D. \& Villeval, M.C. (2013). "The Dark Side of Competition for Status", Management Science, 60(1), 38-55.

Chong, D. \& Druckman, J.M. (2007). "Framing Public Opinion in Competitive Democracies", American Political Science Review, 101(4), 637-655.

Clark, A.E., Kristensen, N. \& Westergard-Nielsen, N. (2009). "Economic Satisfaction and Income Rank in Small Neighbourhoods", Journal of the European Economic Association, 7(2-3), 519-527.

Congdon, W.J., Kling, J.R. \& Mullainathan, S. (2011). Policy and Choice: Public Finance through the Lens of Behavioral Economics, Washington (DC).

Conlisk, J. (1996). "Why Bounded Rationality?”, Journal of Economic Literature, 34, 669-700.

Cooper, J.C. \& Kovacic, W.E. (2012). "Behavioral Economics - Implications for Regulatory Behavior", Journal of Regulatory Economics, 41(1), 41-58.

Cotè, S., House, J. \& Willer, R. (2015). "High Economic Inequality Leads Higher-Income Individuals to be Less Generous", Proceedings of the National Academy of Sciences of the United States of America (PNAS), 112(52), 15838-15843.

Courant, P., Gramlich, E. \& Rubinfeld, D. (1979). "The Stimulative Effects of Intergovernmental Grants - Or Why Money Sticks Where It Hits", Fiscal Federalism and Grants in Aid, (Hrsg.) Mieszkowski, P. \& W. Oakland, The Urban Institute, Washington (D.C.), 5-21

Cruces, G., Truglia, R.P. \& Tetaz, M. (2011). Biased Perception of Income Distribution and Preferences for Redistribution - Evidence from Survey Experiment, IZA Discussion Paper 5699, IZA, Bonn.

Della Vigna, S. (2009). "Psychology and Economics", Journal of Economic Literature, 47(2), 315372.

Dollery, B.E. \& Worthington, A.C. (1999). "Fiscal Illusion at the Local Level - An Empirical Test Using Australian Municipal Data", Economic Record, 75(1), 37-48.

Döring, T. \& Oehmke, R.D. (2019). "About the Economic Psychology of Public Debt", Intereconomics, 54(5), 297-303.

Downs, A. (1960). "Why the Government Budget is too small in a Democracy", World Politics, 12(4), 541-563.

Elster, J. (1998). "Emotions and Economic Theory", Journal of Economic Literature, 36(1), 47-74.

Falk, A., Fehr, E. \& Zehnder, C. (2006). "Fairness Perception and Reservation Wages - The Behavioral Effects of Minimum Wages Law", The Quarterly Journal of Economics, 121(4), 1347-1381. 
Döring, T. \& Oehmke, R. D. (2020). "Behavioral Economics and Government Purchases - Some Insights into the Fiscal Psychology of Public Expenditure", International Journal of Public Finance, 5(1), 56-80.

Fehr, E. \& Schmidt, K.M. (1999). "A Theory of Fairness, Competition and Cooperation", Quarterly Journal of Economics, 114(3), 817-868.

Fernbach, P.M., Rogers, T., Fox, C.R. \& Sloman, S.A. (2013). "Political Extremism Is Supported by an Illusion of Understanding", Psychological Science, 24(6), 939-946.

Ferrer-i-Carbonell, A. (2005). "Income and Well-Being - An Empirical Analysis of the Comparison Income Effect", Journal of Public Economics, 89(5-6), 997-1019.

Frey, B.S. \& Eichenberger R. (1991). "Anomalies in Political Economy", Public Choice, 68(1-3), 7189.

Glaeser, E.L. (2003). Psychology and the Market, Harvard Institute of Economic Research, Discussion Paper, No. 2023.

Grund, Ch. \& Sliwka, D. (2007). "Reference-Dependent Preferences and the Impact of Wage Increases on Job Satisfaction - Theory and Evidence", Journal of Institutional and Theoretical Economics, 163(2), 313-335.

Güth, W., Schmittberger, R. \& Schwarze, B. (1982). "An Experimental Analysis of Ultimatum Bargaining", Journal of Economic Behavior and Organization, 3(4), 367-388.

Hamlin, A. \& Jennings, C. (2011). "Expressive Political Behaviour - Foundations, Scope and Implications", British Journal of Political Science, 41(3), 645-670.

Hammes, D.L. \& Wills, D.T. (1987). "Fiscal Illusion and the Grantor Government in Canada", Western Economic Association International, 25(4), 707-713.

Henrich, J., Boyd, R., Bowles, S., Camerer, C., Fehr, E. \& Gintis, H. (2004). Economic Experiments and Ethnographic Evidence from Fifteen Small-Scale Societies, Oxford.

Hillman, A.L. (2010). "Expressive Behavior in Economics and Politics", European Journal of Political Economy, 26(4), 403-418.

Hines, J. \& Thaler, R. (1995). "Anomalies - The Flypaper Effect", Journal of Economic Perspectives, 9(4), 217-226.

Jolls, Ch., Sunstein, C.R. \& Thaler, R. (1998). "A Behavioral Approach to Law and Economics", Stanford Law Review, 50, 1471-1550.

Jones, P. \& Hudson, J. (2000). "Civic Duty and Expressive Voting - Is Virtue its own Reward?", Kyklos, 53(1), 3-16.

Kahneman, D. \& Tversky, A. (1979). "Prospect Theory - An Analysis of Decision under Risk", Econometrica, 47(2), 263-291.

Kahneman, D. \& Tversky, A. (1984). "Choices, Values and Frames", American Psychologist, 39(4), 341-350.

Kahneman, D. \& Tversky, A. (1992). "Advances in Prospect Theory - Cumulative Representation of Uncertainty", Journal of Risk and Uncertainty, 5(4), 297-323.

Kahneman, D. (2003). "Maps of Bounded Rationality: Psychology for Behavioral Economics", American Economic Review, 93(5), 1449-1475.

Kahneman, D. (2011). Thinking, Fast and Slow, London.

Kahneman, D., Knetsch, J.L. \& Thaler, R. (1991). "Anomalies - The Endowment Effect, Loss Aversion and Status Quo Bias", Journal of Economic Perspectives, 5(1), 193-206. 
Döring, T. \& Oehmke, R. D. (2020). "Behavioral Economics and Government Purchases - Some Insights into the Fiscal Psychology of Public Expenditure", International Journal of Public Finance, 5(1), 56-80.

Keynes, J.M. (1936). The General Theory of Employment, Interest, and Money, London.

Kilavuz, F. \& Yüksel, C. (2019). "Psychological and Sociological Factors Weakening Public Budget Awareness", International Journal of Public Finance, 4 (2), 127-144.

Kirchler, E. (1997). "Balance between Giving and Receiving - Tax Morality and Satisfaction with Fiscal Policy as They Relate to the Perceived Just Distribution of Public Resources", International Journal of Economic Studies, 5, 59-70.

Kirchler, E. (1999). "Reactance to Taxation - Employers' Attitudes toward Taxes", Journal of Socio Economics, 28(2), 131-138.

Kirchler, E. (2007). The Economic Psychology of Tax Behaviour, Cambridge.

Kuran, T. \& Sunstein, C. (1999). "Availability Cascades and Risk Regulation", Stanford Law Review, 51(4), 683-768.

Kuran, T. (1991). "Cognitive Limitations and Preference Evolution", Journal of Institutional and Theoretical Economics, 147(2), 241-273.

Kurtz, J.L. (2008). "Looking at the Future to Appreciate the Present - The Benefits of Perceived Temporary Scarcity", Psychological Science, 19(12), 1238-1241.

Layard, R. (2005). Happiness - Lessons from a New Science, New York.

Lewis, A. (1983). "Public Expenditures - Perceptions and Preferences", Journal of Economic Psychology, 3(2), 159-167.

Linville, P.W. (1985). "Self-Complexity and Affective Extremity - Don't Put All of Yours Eggs in One Cognitive Basket", Social Cognition, 3(1), 94-120.

Mankiw, N.G. (2018). Macroeconomics, 10th Edition, Basingstoke and New York.

Milkman, K.L., Mazza, M.C., Shu, L.L., Tsay, C.-J. \& Bazerman, M. (2012). “Policy Bundling to Overcome Loss Aversion - A method for Improving Legislative Outcome", Organizational Behavior and Human Decision Processes, 117(1), 158-167.

Mullainathan, S. \& Shafir, E. (2013). Scarcity - Why Having Too Little Means So Much, New York.

Mullainathan, S., Schwartzstein, J. \& Congdon, W.J. (2012). "A Reduced-Form Approach to Behavioral Public Finance", Annual Review of Economics, 4(17), 511-540.

Oates, W.E. (1979). "Lump-Sum Intergovernmental Grants Have Price Effects", Fiscal Federalism and Grants in Aid, (Hrsg.) Mieszkowski, P. \& W. Oakland, Washington (DC), 23-30.

Oates, W.E. (1988). "On the Nature and Measurement of Fiscal Illusion: A Survey", Taxation and Fiscal Federalism, (Ed.) Brennan, G., Grewel, B.S. \& P. Groenwegen, Sydney, 65-82.

Payne, J.W., Bettman, J.R. \& Johnson, E.J. (1992). "Behavioral Decision Research: A Constructive Processing Perspective", Annual Review of Psychology, 43, 87-131.

Peacock, A.T. \& Wiseman, J. (1961). The Growth of Public Expenditure in the United Kingdom, Princeton.

Praag, B.M.S.von \& Frijters, P. (1999). "The Measurement of Welfare and Well-Being - The Leyden Approach", Well-Being - The Foundations of Hedonic Psychology, (Ed.) Kahneman, D., Diener, E. \& N. Schwarz, New York, 413-433.

Quattrone, G.A. \& Tversky, A. (1988). "Contrasting Rational and Psychological Analysis of Political Choice", American Political Science Review, 82(3), 719-736. 
Döring, T. \& Oehmke, R. D. (2020). "Behavioral Economics and Government Purchases - Some Insights into the Fiscal Psychology of Public Expenditure", International Journal of Public Finance, 5(1), 56-80.

Rabin, M. (1993). "Incorporating Fairness into Game Theory and Economics", American Economic Review, 83(5), 1281-1302.

Rabin, M. (1998). "Psychology and Economics", Journal of Economic Literature, 36(1), 11-46.

Roemer, J.E. \& Silvestre, J. (2005). The ,Flypaper Effect' is not an Anomaly. Cowles Foundation Paper 1113, New Haven.

Schmölders, G. (1960). Das Irrationale in der öffentlichen Finanzwirtschaft - Probleme der Finanzpsychologie, Rowohlt, Hamburg.

Schmölders, G. (1970). Finanz- und Steuerpsychologie, Rowohlt, Hamburg.

Schnellenbach, J. \& Schubert, C. (2015). "Behavioral Political Economy: A Survey", European Journal of Political Economy, 40(Part B), 395-417.

Seligman, M.E. (1975). Helplessness - On Depression, Development and Death, San Francisco.

Smith, V.L. (2005). "Behavioral Economics Research and the Foundations of Economics", Journal of Socio-Economics, 34(2), 35-150.

Smith, V.L. (2008). Rationality in Economics, New York.

Spicer, M.W. \& Lundstedt, S.B. (1975). A Reexamination of Taxpayer Behavior, Columbus.

Thaler, R. (1985). "Toward A Positive Theory of Consumer Choice", Journal of Economic Behavior and Organization, 1(1), 39-60.

Thaler, R. (1988). "Anomalies - The Ultimatum Game", Journal of Economic Perspectives, 2(4), 195-206.

Thaler, R.H. \& Sunstein, C.R. (2009). Nudge - Improving Decisions about Health, Wealth and Happiness, New York et al.

Tompkinson, P. \& Bethwaite, J. (1991). "The Effect of Information on Fiscal Perception", Journal of Economic Psychology, 12(2), 287-298.

Tyran, J.-R. (2004). "Voting when Money and Morals Conflict - An Experimental Test of Expressive Voting", Journal of Public Economics, 88(7-8), 1645-1664.

Variyam, J.M. \& Jordan, J.L. (1991). "Economic Perceptions and Agricultural Policy Preferences", Western Journal of Agricultural Economics, 16(2), 304-314.

Wildasin, D.E. (1990). "Budgetary Pressures in the EEC - A Fiscal Federalism Perspective", American Economic Review, 80(2), 69-74.

Wildavsky, A. (1964). The Politics of the Budgetary Process, Boston.

Wood, W. \& Neal, D.T. (2007). "A New Look at Habits and the Habit-Goal Interface", Psychological Review, 114(4), 843-863.

Wortmann, C.B. \& Brehm, J.W. (1975). "Responses to Uncontrollable Outcomes - An Integration of Reactance Theory and the Learned Helplessness Model", Advances in Experimental Social Psychology 8, (Ed.) Berkowitz, L., New York and London, 277-336.

Wyckoff, P.G. (1991). "The Elusive Flypaper Effect", Journal of Urban Economics, 30(3), 310-328. 